DOI: $10.15290 /$ bsp.2020.25.02.16

Received: 31.03 .2020

Accepted: 16.06 .2020

\title{
Aleksandra Cekała
}

Uniwersytet Wrocławski, Polska

aleksandracekala@wp.pl

\section{Artur Nowak}

Uniwersytet Wrocławski, Polska

arti7991@gmail.com

\section{Obowiązek udzielenia informacji prasie a tajemnica medyczna}

\author{
Medical Confidentiality vs. Press Inquiry
}

\begin{abstract}
Medical confidentiality is a legally regulated principle of professional ethics, which not only protects patients from the disclosure of their confidential data, but also constitutes limitations on the possibility of transferring information between healthcare providers and the press. This article has two main objectives. To show the impact of medical confidentiality on journalistic activities, in particular on the procedure of providing information to the press as part of a press inquiry. The second goal is to display to both sides of the conflict of interest certain patterns of correct behaviour, and their rights and duties towards not only each other, but also the patient.
\end{abstract}

Keywords: medical confidentiality, press laws, medical law, press, information, patient

Słowa kluczowe: tajemnica medyczna, prawo prasowe, prawo medyczne, informacja, prasa, pacjent

\section{Wprowadzenie}

Wolność to wartość fundamentalna, a stwierdzenia takie jak wolność słowa, wolność mediów, wolność poglądów czy wolność przepływu informacji towarzyszą nam na co dzień. Korzystając z prawa do wolności wypowiedzi, dziennikarz ma za zadanie przekazywać rzetelne informacje i ułatwiać obywatelom dostęp do życia publicznego. Zagwarantowane mu uprawnienia, niezbędne do prawidłowego i rzetelnego wykonywania zawodu, zostały jednak pozbawione charakteru absolutnego, aby ograniczyć możliwość naruszenia praw osób trzecich. Niewątpliwym jest, że dziennikarze są wszędzie tam, gdzie można zdobyć informacje budzące zainteresowanie. Personel medyczny w trakcie terapii pacjenta także uzyskuje te wrażliwe, pożądane 
przez społeczeństwo dane. Przeszkodą dla szkodliwego upowszechniania się informacji poufnych jest instytucja tajemnicy medycznej. W ten sposób dochodzi do konfliktu chronionych dóbr. Przyjmuje się, że „wolność człowieka kończy się tam, gdzie zaczyna się wolność drugiego człowieka”. Powstaje zatem pytanie, czy w obliczu istnienia obowiązku udzielenia informacji prasie lekarz ma prawo skutecznie zasłonić się tajemnicą medyczną dla dobra pacjenta. Czy istnieją metody przekazywania informacji w sposób niełamiący praw oraz interesów stron zainteresowanych? Czy $\mathrm{w}$ takim razie podmioty medyczne mają obowiązek czy uprawnienie z nich korzystać? Celem niniejszego opracowania jest odpowiedź na te pytania.

\section{Pojęcie, zakres oraz charakter tajemnicy medycznej}

Tajemnica medyczna znana jest od czasów starożytnych. Adepci sztuki leczenia, składając przysięgę Hipokratesa, ślubowali: „Cokolwiek bym podczas leczenia, czy poza nim, z życia ludzkiego ujrzał czy usłyszał, czego nie należy na zewnątrz rozgłaszać, będę milczał, zachowując to w tajemnicy". Słowa te obrazują delikatną relację pomiędzy lekarzem a pacjentem. Aby funkcjonowała ona poprawnie, powinna być budowana od podstaw na zaufaniu. Pozbawiona tego aspektu może znacznie utrudnić leczenie, a nawet uniemożliwić. Brak zaufania może skutkować zatajeniem przez pacjenta informacji kluczowych dla postawienia właściwej diagnozy.

Obecnie obowiązek przestrzegania tajemnicy medycznej wynika z przepisów kodeksu etyki lekarskiej i ustawy o zawodach lekarza i lekarza dentysty, a także z ustawy o prawach pacjenta i Rzeczniku Praw Pacjenta (u.p.p.r.p.p.). Przepisy dotyczące tej tematyki znajdziemy nie tylko w polskim systemie prawnym. Wprawdzie tajemnica medyczna nie jest przedmiotem regulacji w Europejskiej Konwencji o Ochronie Praw Człowieka i Podstawowych Wolności, jednak w orzecznictwie Europejskiego Trybunału Praw Człowieka akcentuje się daleko idącą ochronę danych medycznych, a tym samym prywatności pacjenta ${ }^{2}$. Zobowiązanie do zachowania dyskrecji medycznej zostało również przyjęte w Deklaracji Genewskiej z 1948 r. ${ }^{3}$ przez Światowe Stowarzyszenie Lekarzy. Tajemnica medyczna, rodzaj tajemnicy zawodowej, stanowi gwarancję poszanowania prywatności pacjenta jako dobra chronionego przez Kon-

1 Kodeks Etyki Lekarskiej, https://www.nil.org.pl/_data/assets/pdf_file/0003/4764/Kodeks-Etyki -Lekarskiej.pdf (30.12.2019), ustawa z dnia 5 grudnia 1996 r. o zawodach lekarza i lekarza dentysty (tekst jedn. Dz.U. z 2019 r. poz. 537 ze zm.) oraz ustawa z dnia 6 listopada 2008 r. o prawach pacjenta i Rzeczniku Praw Pacjenta (tekst jedn. Dz.U. z 2019 r. poz. 1127 ze zm.).

2 J. Sobczak, Tajemnica lekarska w obliczu zmian, MW 9/2017, https://www.nil.org.pl/_data/assets/pdf_file/0011/128783/04-Sobczak.pdf (30.12.2019).

3 Deklaracja Genewska z 1948 r., https://www.wma.net/policies-post/wma-declaration-of-geneva/ (30.12.2019). 
stytucję Rzeczypospolitej Polskiej ${ }^{4}$. Obejmuje szereg danych związanych z pacjentem, m.in. dotyczących jego stanu zdrowia, metod oraz wyników dotychczasowego i aktualnego leczenia, historii choroby, uzależnień, a także relacji rodzinnych, życia zawodowego, poziomu inteligencji, stanu majątkowego oraz osób z otoczenia, o których lekarz dowiedział się w związku z wykonywanym zawodem. Niezależnie od miejsca i sposobu ich utrwalenia rozciąga się na wszelkie materiały (papierowe czy elektroniczne $)^{5}$. Interesem prawnym pacjenta oraz jego potrzebą psychologiczną jest, żeby informacje związane $\mathrm{z}$ dotyczącym go postępowaniem medycznym nie zostały ujawnione ${ }^{6}$. Zachować tajemnicę medyczną ustawowo mają obowiązek nie tylko lekarze i personel medyczny, ale i podmioty prowadzące działalność leczniczą oraz udzielające świadczeń zdrowotnych. Dostęp do chronionych informacji o pacjencie ma wyłącznie osoba bezpośrednio zaangażowana w proces leczenia ${ }^{7}$. Zgodnie $\mathrm{z}$ art. 24 Kodeksu Etyki Lekarskiej (dalej: k.e.l.) przekazanie informacji o stanie pacjenta innemu lekarzowi następuje tylko wtedy, gdy jest to niezbędne dla dalszego leczenia lub wydania orzeczenia o jego stanie zdrowia. Sam fakt posiadania statusu lekarza czy osoby z personelu medycznego nie jest wystarczający do uzyskania dostępu do danych poufnych. Zdarza się, że poufność oczekiwana przez pacjenta zostaje zastąpiona jednoznacznym obowiązkiem udzielania informacji władzom publicznym ${ }^{8}$. Przypadki, w których wyłączenie dyskrecji medycznej jest możliwe, wynikają z treści art. 40 ust. 2 ustawy o zawodach lekarza i lekarza dentysty (dalej u.z.l.). Lekarz będzie zwolniony z obowiązku zachowania tajemnicy medycznej, gdy: możliwość taką przewidują ustawy; badanie lekarskie zostało przeprowadzone na żądanie uprawnionych organów i instytucji; zachowanie tajemnicy w sposób istotny zagraża zdrowiu lub życiu pacjenta lub innych osób; a także gdy pacjent lub jego przedstawiciel ustawowy wyrazi na to zgodę, po uprzednim poinformowaniu pacjenta o niekorzystnych dla niego skutkach jej ujawnienia.

Nie stanowi naruszenia tajemnicy medycznej sytuacja, w której zostaną udostępnione informacje dotyczące pacjenta, ale na ich podstawie nie będzie możliwa identyfikacja czy powiązanie danych z konkretną osobą. Taką okoliczność wskazuje art. 28 u.z.l. - informacja uzyskana w związku z eksperymentem medycznym może być wykorzystana do celów naukowych, bez zgody osoby poddanej temu eksperymentowi, jednakże w sposób uniemożliwiający identyfikację tej osoby. Również art.

4 Z. Wierzchoń, Wykonuję zawód lekarz, lekarz dentysta. Komentarz do ustawy, Kodeks Etyki Lekarskiej, 2017, s. 523.

5 J. Sobczak, Tajemnica lekarska, MW 8/2016, https://www.nil.org.pl/_data/assets/pdf_ file/0010/112015/06- Sobczak.pdf (30.12.2019).

6 J. Jabłońska, Tajemnica lekarska jako podstawa zaufania w relacji pacjent - lekarz, MW 4/2012, https://wil.org.pl/wp-content/uploads/4_2012.pdf (30.12.2019).

7 M. Olejniczak, Tajemnica lekarska - prawo rodzące zaufanie, (w:) M. Safjan (red.), Prawne i etyczne problemy współczesnej medycyny, Olsztyn 2016, s. 43.

8

J. Sobczak, Tajemnica..., op. cit. 
40 ust. 4 u.z.l. stanowi, że lekarz nie może podać do publicznej wiadomości danych umożliwiających identyfikację pacjenta bez jego zgody. Spoza zakresu tajemnicy wyłączone są informacje powszechnie znane lub takie, o których treści każdy nimi zainteresowany może się legalnie dowiedzieć 9 .

Obowiązek zachowania tajemnicy medycznej nie ulega przedawnieniu. Lekarz pozostaje nim związany nawet po śmierci pacjenta. Pomimo że zmarły nie jest już podmiotem prawa, to z szacunku do niego jako do osoby, która ma prawo decydować o swoich dobrach osobistych, przyjęto, że tajemnica nie wygasa (art. 23 k.e.l.). Takie działanie wzmacnia zaufanie pacjentów do profesji lekarskiej, co leży w interesie obu stron $^{10}$. Wyjawieniu tajemnicy medycznej po śmierci pacjenta może sprzeciwić się pacjent za życia oraz osoba bliska (art. 3 ust. 1 pkt 2 u.p.p.r.p.p.). Pomimo sprzeciwu sąd może orzec o ujawnieniu informacji, jeśli jest to niezbędne na przykład w celu dochodzenia odszkodowania lub zadośćuczynienia z tytułu śmierci pacjenta oraz dla ochrony życia lub zdrowia osoby bliskiej.

Naruszenie obowiązku zachowania tajemnicy medycznej prowadzi do odpowiedzialności cywilnej, karnej i dyscyplinarnej. Sankcje można stosować równolegle. $\mathrm{W}$ prawie cywilnym dane dotyczące pacjenta zabezpieczone są poprzez instrumenty ochrony dóbr osobistych ${ }^{11}$. Poszkodowanemu przysługuje prawo do odszkodowania, a także do zadośćuczynienia. Odpowiedzialność karna wynika z art. 266 k.k. ${ }^{12}$ Za naruszenie przepisu kodeks przewiduje karę grzywny, ograniczenia wolności lub pozbawienia wolności do lat dwóch. Przestępstwo to ma charakter umyślny. Odpowiedzialność zawodową lekarza ocenia sąd lekarski. Przepisy wskazują, że w takich wypadkach za naruszenie tajemnicy medycznej może zostać nałożona kara pieniężna, upomnienie, nagana, a także zakaz pełnienia funkcji kierowniczych w jednostkach organizacyjnych ochrony zdrowia na okres od roku do pięciu lat, ograniczenie zakresu czynności w wykonywaniu zawodu lekarza na okres od sześciu miesięcy do dwóch lat, zawieszenie prawa wykonywania zawodu na okres od roku do pięciu lat oraz pozbawienie prawa wykonywania zawodu.

\section{Obowiązek udzielenia informacji prasie}

Artykuł 14 Konstytucji RP jest gwarantem wolności prasy i innych środków przekazu, a art. 54 - wolności do wyrażania swoich poglądów oraz pozyskiwania i rozpowszechniania informacji. To z nich wynika prawo dostępu do rzetelnej informacji (czyli prawdziwej, uczciwej, jasnej, niewprowadzającej w błąd, odpowiedniej), które potencjalnie może stać $\mathrm{w}$ konflikcie z innymi wartościami konstytucyjnymi,

$9 \quad$ Wyrok SN z dnia 5 września 2001 r., I CKN 1159/00, Legalis nr 51073.

10 M. Olejniczak, Tajemnica..., op. cit., s. 46-47.

11 K. Świtała, Tajemnice zawodów medycznych - podstawowa charakterystyka, Legalis (30.12.2019).

12 Ustawa z dnia 6 czerwca 1997 r. - Kodeks karny (tekst jedn. Dz.U. z 2019 r. poz. 1950 ze zm.). 
np. sferą prywatną jednostki. Efektem konfliktu są ograniczenia i limity prawa prasowego celem ochrony dobrego imienia i praw innych osób. Wolność prasy nie jest bezkresna, co potwierdzają wyroki SN: „korzystanie przez dziennikarza z gwarantowanej mu swobody nie może prowadzić z kolei do naruszania praw innych osób ${ }^{13}$, zaś wolność prasy jest jedną z wolności politycznych, które w praktyce mogą doznawać ograniczeń $\mathrm{z}$ uwagi na konieczność zapewnienia wolności jednostki. Tak więc wolność prasy nie ma i nie może mieć charakteru absolutnego, nie może mieć postaci nieskrępowanej niczym swobody działania, a tym bardziej nie sposób jej traktować jako samoistnego źródła wartości" ${ }^{14}$. W dobie cyfryzacji i szybkiego obiegu informacji lekarze muszą być bardzo ostrożni, aby zachować tajemnicę zawodową, lecząc nie tylko celebrytów, ale też zwykłych obywateli będących ofiarami nieszczęśliwych wypadków i chorób. Dane będące w ich posiadaniu mają bardzo wrażliwą naturę, a upublicznione przez prasę mogą mieć szkodliwe skutki dla sfery prywatnej jednostki oraz jej dóbr osobistych. Kto więc ma obowiązek udzielać informacji o stanie pacjenta? Komu można udzielać te dane? Kiedy dochodzi do naruszenia tajemnicy oraz czy zawsze należy odpowiadać na zapytania prasy?

\subsection{Katalog podmiotów zobowiązanych do udzielenia informacji}

Na podstawie art. 11 ust. 1 p.p. ${ }^{15}$ w związku z art. 4 ust. 1 dziennikarz może domagać się od pewnych podmiotów udzielenia informacji, a mianowicie od przedsiębiorców, podmiotów niezaliczonych do sektora finansów publicznych oraz podmiotów niedziałających w celu osiągnięcia zysku. Do pierwszej grupy zaliczamy osoby udzielające świadczeń zdrowotnych prowadzących działalność leczniczą. Lekarze i pielęgniarki wykonują swój zawód w ramach praktyki zawodowej, która często przybiera formę jednoosobowej działalności gospodarczej, spółki cywilnej, spółki jawnej albo spółki partnerskiej (art. 5 d.l.u.) ${ }^{16}$. Działalność lecznicza to szczególny rodzaj działalności, regulowany w rozumieniu ustawy Prawo przedsiębiorców (art. 16 ust. 1 d.l.u.). Musi ona spełniać szereg dodatkowych warunków i uzyskać wpisy do odpowiednich rejestrów (art. 43 pr. przed.) ${ }^{17}$. Lekarze i pielęgniarki, wykonujący zawód w ramach praktyki zawodowej we własnym imieniu, mają status przedsiębiorcy, co obliguje ich do przekazywania informacji prasie. Powinność ta ciąży również na innych podmiotach leczniczych, np. spółkach handlowych prowadzących szpitale (art. 4 ust. 1 pkt 1 d.l.u.). W grupie podmiotów nienależących do sektora finansów publicznych obowiązek taki mają podmioty prowadzące działalność non profit. Zaliczamy do nich

13 Wyrok SN z dnia 20 lutego 2004 r., I CK 19/04, Legalis nr 70698.

14 Postanowienie SN z dnia 12 listopada 2003 r. V KK 52/03, Legalis nr 61983.

15 Ustawa z dnia 26 stycznia 1984 r. Prawo prasowe (tekst jedn. Dz.U. z 2018 r. poz. 1914).

16 Ustawa z dnia 15 kwietnia 2011 r. o działalności leczniczej (tekst jedn. Dz.U. z 2018 r. poz. 2190 ze zm.).

17 Ustawa z dnia 6 marca 2018 r. - Prawo przedsiębiorców (tekst jedn. Dz.U. z 2019 r. poz. 1292 ze $\mathrm{zm}$.). 
stowarzyszenia, fundacje, kościoły i związki wyznaniowe o statusie podmiotu leczniczego (art. 4 ust. 1 d.l.u.). Warto przypomnieć, że na gruncie ustawy o działalności leczniczej szpital traktuje się jako przedsiębiorstwo podmiotu leczniczego ${ }^{18}$. Właściwością podmiotów zinstytucjonalizowanych jest powinność udzielania informacji tylko przez wyznaczone osoby. Zgodnie z art. 11 ust. 2 p.p. są to kierownicy tych jednostek, ich zastępcy, rzecznicy prasowi bądź osoby upoważnione w granicach powierzonych im zadań. Na innych pracownikach obowiązek ten nie ciąży (w ramach art. 5 p.p. $)^{19}$. Przysługuje im prawo do odmowy udzielenia informacji bez poniesienia konsekwencji prawnych. Powinny jednak odesłać dziennikarza do osoby upoważnionej $^{20}$. Zgoda na przekazanie informacji prasie nie jest równoznaczna ze zgodą na publikację zapisów fonicznych i wizualnych udzielającej jej osoby. O taką zgodę dziennikarz powinien wystąpić oddzielnie ${ }^{21}$. Podmioty zobowiązane do udzielania informacji nie mogą stwarzać warunków uniemożliwiających dziennikarzom swobodne zbieranie informacji. Zgodnie z wyrokiem NSA istnieje pozytywny obowiązek sprowadzający się do „stworzenia dziennikarzom możliwości zapoznania się z informacją"22.

\subsection{Katalog podmiotów uprawnionych do uzyskania informacji}

Z powyższych rozważań wynika, że istnieje krąg podmiotów ustawowo zobowiązanych do przekazywania informacji prasie. Trzeba skonkretyzować, wobec kogo należy spełnić ten obowiązek. Komu zgodnie z prawem można udzielić informacji? Wyjść trzeba od pojęcia prasy, które zgodnie ze Słownikiem języka polskiego PWN oznacza „ogół ludzi piszących w czasopismach”"23. W świetle ustawy Prawo prasowe osobami takimi będą dziennikarze, redaktorzy i redaktorzy naczelni. Osoba taka zajmuje się redagowaniem, tworzeniem lub przygotowaniem materiałów prasowych, pozostaje $\mathrm{w}$ stosunku pracy z redakcją albo zajmuje się taką działalnością na rzecz i z upoważnienia redakcji ${ }^{24}$. Dyspozycja art. 4 p.p. odnosi się także do prasy zagranicznej $^{25}$. W wyroku NSA z dnia 13 stycznia 2016 r. postawiono następującą tezę: „Aby wniosek składany w trybie art. 4 ust. 1 p.p. mógł być rozpoznany zgodnie $\mathrm{z}$ przepisami ustawy Prawo prasowe, nie jest wystarczające powołanie się przez

18 R. Kubiak, Tajemnica medyczna, Warszawa 2015, rozdział X: Tajemnica medyczna a prawo prasowe, s. 5, Legalis (07.01.2020).

19 Wyrok WSA z dnia 03 sierpnia 2010 r., II SA/Bd 511/10, Legalis nr 873624.

20 Wyrok NSA z dnia 27 czerwca 1996 r., II SAB/Kr 36/96, Legalis nr 40267.

21 B. Kosmus, G. Kuczyński, Prawo prasowe. Komentarz, Warszawa 2018, art. 11 III. Kontakty pracowników z prasą, ust. 10, Legalis (07.01.2020).

22 Ibidem, art. 11 III. Kontakty pracowników z prasą ust. 1, Legalis (07.01.2020) oraz Wyrok NSA z dnia 23 lutego 1999 r., II SA 73/99, Legalis nr 43227.

23 Słownik języka polskiego PWN, https://sjp.pwn.pl/szukaj/prasa.html (02.01.2019).

24 Ustawa - Prawo prasowe - art. 7 ust. 2 pkt 5-7.

25 B. Kosmus, G. Kuczyński, Prawo..., op. cit., art. 4 II. Podmioty uprawnione, ust.2, Legalis (07.01.2020). 
kogokolwiek na fakt bycia dziennikarzem nawet konkretnego tytułu prasowego, jak i na upoważnienie redaktora naczelnego. Koniecznym jest wykazanie, że wniosek ten pochodzi od prasy w rozumieniu art. 7 ust. 2 pkt 1 p.p." ${ }^{26}$ Lekarz ma prawo żądać od podmiotu wnioskującego, przed udzieleniem informacji, okazania odpowiednich dokumentów, takich jak legitymacja czy akredytacja.

\subsection{Zakres przedmiotowy prawa do informacji}

Udzielana informacja powinna ograniczać się wyłącznie do faktów i ustaleń, gdyż taka jest istota obowiązku informacyjnego. Dziennikarze nie mogą domagać się przekazania im ocen, opinii, przemyśleń czy przeżyć i procesów psychicznych lekarzy i innych osób ${ }^{27}$. Lekarz nie ma obowiązku tworzenia czy przetwarzania jej w formie wykazów, spisów, zestawień czy innego rodzaju opracowań. Co innego tyczy się udostępniania danych już istniejących ${ }^{28}$. Prawo nie upoważnia prasy do przerzucania swoich obowiązków na podmioty zobowiązane do przekazywania informacji ${ }^{29}$. Odpowiedź udzielona prasie nie może być niepełna, nierzeczowa - lakoniczna. Zostanie wtedy potraktowana jako odmowa udzielenia informacji oraz zbycie dziennikarza, a więc łamanie jego prawa do informacji ${ }^{30}$. Lekarz nie może żądać zapłaty, pomimo że udzielając informacji, poniesie pewien koszt ${ }^{31}$. Możliwe jest jednak pobieranie opłat od pacjenta za sporządzenie kopii dokumentacji medycznej pacjenta (w wysokości 0,0002 przeciętnego miesięcznego wynagrodzenia za poprzedni kwartał za stronę $)^{32}$. Jeśli pacjent wyraził zgodę na przekazywanie dokumentacji prasie, dozwolony będzie pobór takiej opłaty ${ }^{33}$.

Istnieje spór dotyczący wglądu do dokumentacji medycznej. Sąd Najwyższy uznał, że udzielenie informacji nie ogranicza się jedynie do poinformowania prasy, lecz także do udostępnienia źródeł tych informacji ${ }^{34}$. Zdaniem doktryny pogląd ten jest sprzeczny z literalnym brzmieniem przepisu art. 4 ust 1 p.p., który stanowi o udzielaniu, a nie o udostępnianiu. Powyższe wątpliwości rozwiewa fakt, iż dane za-

26 Wyrok NSA z dnia 13 stycznia 2016 r., I OSK 302/15, Legalis nr 1408088.

27 B. Kosmus, G. Kuczyński, Prawo..., op. cit., art. 4 IV. Zakres obowiązku, ust. 1, Legalis (07.01.2020).

28 Wyrok NSA z dnia 24 czerwca 1999 r., II SA 686/99, Legalis nr 64992.

29 Wyrok NSA z dnia 23 lutego 1999 r., II SA 73/99, Legalis nr 43227.

30 Wyrok WSA z dnia 4 marca 2014 r., II SA/Wa 2238/13, Legalis nr 792959 oraz B. Kosmus, G. Kuczyński, Prawo..., op. cit., art. 4 IV. Zakres obowiązku, ust. 11, Legalis (07.01.2020).

31 Ibidem, art. 4 IV Zakres obowiązku ust. 13, Legalis (07.01.2020).

32 Komunikat w sprawie przeciętnego wynagrodzenia w trzecim kwartale $2019 \mathrm{r}$. https://stat.gov.pl/ sygnalne/komunikaty-i-obwieszczenia/lista-komunikatow-i-obwieszczen/komunikat-w-sprawie -przecietnego-wynagrodzenia-w-trzecim-kwartale-2019-r-,271,26.html (03.01.2020) - Na dzień 3 stycznia $2020 \mathrm{r}$. kwota ta wyniosłaby 99 groszy - zgodnie z danymi podanymi przez GUS.

33 https://oilgdansk.pl/najczesciej-zadawane-pytania/pacjent-zwrocil-sie-do-mnie-o-kopie-swojej-dokumentacji-medycznej-czy-i-w-jakiej-wysokosci-moge-pobrac-od-niego-z-tego-tytulu -oplate-nadmieniam-ze-kopiowanie-tej-dokumentacji-jest-bardzo-czasochlon/ (02.01.2020). Wyrok SN z dnia 24 czerwca 2003 r., III RN 95/02, Legalis nr 61034. 
warte w dokumentacji medycznej objęte są tajemnicą medyczną, więc co do zasady nie ma możliwości zapoznania się z ich treścią ${ }^{35}$. Granice udzielenia prasie informacji przez pracowników są wyznaczone przez art. $100 \$ 2$ pkt 4 i 5 k.p..${ }^{36}$ Pracownik powinien dbać nie tylko o dobro zakładu pracy i pracodawcy, ale i zachować w tajemnicy wszelkie informacje ustawowo chronione (wśród nich jest tajemnica zawodowa) ${ }^{37}$.

\subsection{Kwestie formalne wniosku o udzielenie informacji prasie}

Prawo nie stawia żadnych warunków formalnych wobec wniosku o udzielenie informacji. Jego skuteczność zależy od przekazania (ustnie, pisemnie, telefonicznie etc.). WSA w Warszawie orzekł: „aby wniosek był na tyle szczegółowy, aby podmiot zobowiązany do udzielenia informacji mógł ustalić, jaka konkretnie informacja pozostaje w kręgu zainteresowania wnioskodawcy - prasy, tj. o jakim 'wycinku' działalności przedsiębiorcy i podmiotu niezaliczonego do sektora finansów publicznych prasa chce uzyskać informację"38. Nie znajdziemy również w prawie prasowym lub medycznym normy dotyczącej terminu oraz formy udzielenia odpowiedzi, domniemywa się, że niezwłocznie oraz w formie spełniającej oczekiwania wnioskodawcy. Gdyby nie było takiej możliwości, należy poinformować dziennikarza o terminie, w którym odpowiedź będzie możliwa ${ }^{39}$.

\section{Podstawowa zasada działania tajemnicy medycznej}

Najważniejszą zasadą, jaką powinien kierować się lekarz w kontaktach z prasą, jest dyskrecja. Informacje medyczne powinny być przekazywane wyjątkowo przez podmiot uprawniony w sposób, który nie łamie praw osób trzecich. Art. 4 ust 1. p.p. jednoznacznie wskazuje, że jest się zobowiązanym do udzielenia informacji, o ile na podstawie odrębnych przepisów informacje te nie są objęte tajemnicą lub nie naruszają prawa do prywatności. Lekarz ma prawo zasłonić się tajemnicą medyczną przed ciążącym na nim obowiązkiem udzielenia informacji. Wspomniany zakaz ujawniania danych objętych tajemnicą nie jest bezwzględny. Wskazuje się dwie okoliczności pozwalające legalnie poinformować dziennikarza pomimo obowiązku dochowania dyskrecji.

35 R. Kubiak, Tajemnica..., op. cit., rozdział X: Tajemnica medyczna a prawo prasowe, s. 7, Legalis (07.01.2020).

36 Ustawa z dnia 26 czerwca 1974 r. - Kodeks pracy (tekst jedn. Dz.U. z 2019 r. poz. 1040 ze zm.).

37 B. Kosmus, G. Kuczyński, Prawo..., op. cit., art. 11 III. Kontakty pracowników z prasą, ust. 4, Legalis (07.01.2020).

38 Postanowienie WSA z dnia 24 kwietnia 2008 r., II SA/Wa 1536/06, Legalis nr 213599.

39 B. Kosmus, G. Kuczyński, Prawo..., op. cit., art. 4 VI. Procedura ust. 4, Legalis (07.01.2020). 


\subsection{Wyjątki od zasady}

Pierwszą z nich jest zgoda wyrażona przez pacjenta lub przedstawiciela ustawowego. Pacjent ma pełną swobodę w jej kształtowaniu. Może decydować kiedy, w jakiej formie, komu oraz jakie dane może ujawnić lekarz. Ważne jest, aby upoważniający (przede wszystkim chory) był zdolny do skutecznego prawnie składania oświadczeń woli. Gdy pacjent jest nieprzytomny albo o silnie ograniczonej percepcji, wykluczającej możliwość rozstrzygania z rozeznaniem, to pracownik medyczny nie może udzielać informacji prasie ${ }^{40}$.

Specyficzna sytuacja dotyczy pacjentów nieposiadających pełnej zdolności do czynności prawnych. Chodzi tutaj o małoletnich, którzy ukończyli 16 lat i potrzebę ich kumulatywnej zgody na leczenie. Prawo nie rozstrzyga, czy wtedy również wymagane jest od takiej osoby upoważnienie zwalniające z tajemnicy medycznej. Przyjmuje się, że wymagana jest zgoda obu podmiotów - przedstawiciela ustawowego/ rodzica oraz pacjenta. W przypadku małoletniego poniżej 16 roku życia wystarczające będzie upoważnienie przedstawiciela ustawowego. Należy jednak pamiętać, aby poinformować takiego pacjenta o zaistniałej sytuacji i rozważyć jego zdanie. Wynika to $\mathrm{z}$ kwestii poszanowania prawa do intymności, godności oraz praw dziecka. Gdyby przekazane informacje medyczne miały dotyczyć osób trzecich (przypadki zapłodnienia in vitro, przeszczepu itp.), konieczne jest uzyskanie zgody każdej z nich.

Zgoda powinna być udzielona przed przekazaniem danych objętych poufnością. Pacjent powinien zostać zaznajomiony z potencjalnymi skutkami wyjawienia tajemnicy (art. 40 ust 2 pkt 4 u.z.l.). Nie określono warunków formalnych dla zgody. Przyjęto, że dla celów dowodowych najlepiej zachować ją w formie pisemnej. Treść zgody powinna jednoznacznie i precyzyjnie określać zakres podmiotowy, przedmiotowy, miejscowy, temporalny i teologiczny zwolnienia. Tajemnica lekarska bowiem jest ujęta - co do zasady - absolutnie. Jako że mamy do czynienia z wyjątkiem, to wymagana jest dookreśloność. Oczywiście fakty powszechnie znane nie są objęte dyskrecją. Spór toczy się wokół zgody dorozumianej. W pewnych praktycznych sytuacjach jest ona dopuszczalna. Można wyobrazić sobie teoretyczny stan, w którym pacjent, niebędący w stanie wyrazić swojej woli ustnie bądź pisemnie, dokonuje jej gestem.

Zgoda kreuje tylko i wyłącznie uprawnienie dla personelu medycznego do poinformowania mediów. Mimo zezwolenia lekarz nadal nie ma obowiązku udzielania informacji. Pacjent nie może też wymóc informowania prasy o swoim stanie zdrowia i udzielanych świadczeniach zdrowotnych ${ }^{41}$.

Inną możliwością jest przekazanie informacji w sposób zanonimizowany, nienaruszający celu tajemnicy zawodowej. Wymaga on nie tylko ochrony podstawowych

40 R. Kubiak, Tajemnica..., op. cit., rozdział X: Tajemnica medyczna a prawo prasowe, s. 7-8, Legalis (07.01.2020).

41 R. Kubiak, Tajemnica..., op. cit., rozdział X: Tajemnica medyczna a prawo prasowe, s. 8, Legalis (07.01.2020). 
danych osobowych, ale i wszelkich innych, które mogłyby doprowadzić do ustalenia tożsamości pacjenta. Udzielenie informacji tą metodą jest szczególnie utrudnione w przypadku osób publicznych lub indywidualnych zdarzeń losowych, takich jak wypadek samochodowy (a nie przykładowo środków transportu zbiorowego). Skorzystanie z tego uprawnienia leży w gestii lekarza. Dla poszanowania prawa jednostki do prywatności, godności oraz ochrony dóbr osobistych nadal może on zasłonić się tajemnicą medyczną przed obowiązkiem $z$ art. 4 ust. 1 p.p.

\subsection{Kwestia odmowy udzielenia informacji}

Lekarz może dowolnie, a nawet konkludentnie, odpowiedzieć na wniosek dziennikarza. Zatem odpowiedź może być także negatywna przy powołaniu się na tajemnicę medyczną. Uznaje się, że brak reakcji na wniosek dziennikarza to odpowiedź odmowna, bezczynność nie istnieje w sprawach prasowych ${ }^{42}$. Chroniąc się przed brakiem dostępu do informacji, redakcja może wszcząć procedurę, której skutkiem będzie sądowy nakaz udzielenia informacji (art. 4 ust. 3 p.p.). Droga skargi do WSA otwiera się, gdy redaktor naczelny wystąpi z żądaniem doręczenia mu odmowy na piśmie. Niewdrożenie podanego trybu albo wystąpienie przez podmiot nieuprawniony skutkuje brakiem możliwości złożenia skargi ${ }^{43}$. Podana odmowa poza wymogiem pisemności (wykluczono drogę e-mailową oraz faks) ${ }^{44}$ powinna zawierać: oznaczenie organu, jednostki organizacyjnej lub osoby, od której pochodzi, datę jej udzielenia, redakcję, której dotyczy, oznaczenie informacji będącej jej przedmiotem oraz powód odmowy. Powodem może być tajemnica medyczna, z której lekarz nie został zwolniony. Trzy przypadki odpowiedzi: odmowa udzielenia informacji, nieprzekazanie pisemnej odmowy w terminie 3 dni do redakcji (od dnia wpływu żądania) ${ }^{45}$ lub braku w odmowie elementów wskazanych w art. 4 ust. 3 p.p. - umożliwiają redakcji wystąpienie ze skargą do Wojewódzkiego Sądu Administracyjnego w terminie 30 dni (art. 4 ust. 4 p.p.). Sąd po rozpoznaniu sprawy zgodnie z przepisami ustawy Prawo o postępowaniu przed sądami administracyjnymi może zobowiązać dany podmiot do udzielenia informacji. Niewykonanie orzeczenia sądowego skutkować może grzywną $^{46}$. Bezprawna odmowa udzielenia informacji to przestępstwo w myśl art. 49 p.p. w związku z art. 11 ust 2 p.p., które ukarane może być grzywną albo karą ograniczenia wolności. Dotyczy ono jednak tylko osób wskazanych w art. 11 ust. 2 p.p. - zobowiązanych do przekazania danych mediom. Dziennikarz, mimo że nie obowiązuje

42 Wyrok NSA z dnia 11 stycznia 2001 r., II SAB 254/01, Legalis nr 120560.

43 Wyrok WSA z dnia 30 października 2008 r., SA/Wa 1885/07; http://orzeczenia.nsa.gov.pl.

44 Wyrok SA z dnia 29 stycznia 2006 r., I ACa 1589/06, Legalis nr 88000.

45 Odmiennie uważa E. Ferenc-Szydełko, Prawo prasowe. Komentarz, Warszawa 2013, s. 57, która przyjęła, że można stosować przepisy pr. post. adm. czy też k.p.a., więc zachowanie terminu nastąpi poprzez samo nadanie pisma w placówce pocztowej.

46 Do wysokości dziesięciokrotnego przeciętnego wynagrodzenia miesięcznego w gospodarce narodowej w roku poprzednim, ogłaszanego przez prezesa GUS na podstawie odrębnych przepisów. 
Obowiązek udzielenia informacji prasie a tajemnica medyczna

go tajemnica medyczna, również może ponieść odpowiedzialność karną. Przykłady działań, za które będzie odpowiadać, to podżeganie lekarza do wyjawienia tajemnicy zawodowej, zastraszanie go czy kradzież dokumentacji medycznej.

\section{Wybrane przykłady naruszeń tajemnicy medycznej w kontaktach z dziennikarzami}

Problem relacji pomiędzy tajemnicą medyczną a działalnością dziennikarską jest skomplikowany. Niejednokrotnie pracownicy medyczni mają do czynienia z dziennikarzami domagającymi się informacji na temat pacjenta, najczęściej celebryty, polityka czy uczestnika katastrofy. W takich sytuacjach najłatwiej dochodzi do złamania dyskrecji medycznej. Poniżej przytoczono wybrane przykłady naruszeń wraz z analizą popełnionych błędów i odniesieniem do przepisów prawa prasowego oraz karnego.

Kilka lat temu miała miejsce głośna sprawa znanej aktorki - Anny P. Po śmierci kobiety jej lekarz wystąpił w programie telewizyjnym, w którym ze szczegółami opowiadał o powodach cierpienia pacjentki, jej planach życiowych i przeżyciach. Spowodowało to wszczęcie postępowania w sprawie naruszenia art. 23 k.e.l. Okręgowy Sąd Lekarski ukarał lekarza upomnieniem, a Naczelny Sąd Lekarski utrzymał w mocy to orzeczenie. Doktora uznano za winnego popełnienia przewinienia zawodowego, polegającego na ujawnieniu tajemnicy lekarskiej. Wynikało to $\mathrm{z}$ faktu, że nie był $\mathrm{w}$ stanie udowodnić, że skorzystał z uprawnienia do wyjawienia tajemnicy medycznej, a sposób, w jaki udzielił wywiadu, nie był anonimowy, czym naruszył przepisy k.e.l. Dla przykładu mógł mówić o skutkach leczenia nowotworu w sposób ogólny. Wtedy nie byłyby to dane „związane z pacjentem”, lecz stanowiące jedynie element stanu wiedzy medycznej. Przekazując informacje w sposób zanonimizowany, należy wykazać się szczególną ostrożnością. Łatwo podać dane, które pozwolą rozpoznać pacjenta (np. gdy mamy do czynienia z mieszkańcem małej miejscowości). Zachowanie doktora mogło podważyć pozytywny wizerunek oraz społeczne zaufanie do profesji lekarskiej. Mimo że Anna P. była osobą publiczną i w takim wypadku powinno się brać pod uwagę zainteresowanie społeczeństwa przebiegiem choroby, to trzeba podkreślić, że prawo do informacji nie może prowadzić do naruszenia praw innych osób. Błąd został również popełniony przez dziennikarzy. Powszechna praktyka wypytywania o stan zdrowia osób znanych, zwłaszcza w programach na żywo, może stanowić znamiona podżegania $\mathrm{z}$ art. 18 k.k. w związku z art. 266 k.k. ${ }^{47}$ Zawodowy dziennikarz powinien być świadomy, że dane dotyczące kwestii medycznych są objęte tajemnicą ustawowo chronioną. Pomimo że prawo prasowe zobowiązuje

\footnotetext{
47 A. Grzesiok-Horosz, Ograniczenia dostępu prasy do informacji publicznej, https://sbc.org.pl/ Content/305218/Grzesiok-Horosz_159-172.pdf?fbclid=IwAR0WMlSktMZEBOJ4csZNepS5CguGBYDDRlCO6LtiqqtpfDnn-AFdnqdBylc (04.05.2020).
} 
podmioty medyczne do udzielania informacji prasie, to nie jest to obowiązek bezwzględny. Skoro lekarz nie skorzystał z wyjątkowo przysługujących mu uprawnień, to powinien odmówić udzielenia pożądanych przez media informacji. W tym wypadku można również wskazać art. 14 ust. 5 p.p., regulujący sytuacje, w której dziennikarz nie może opublikować informacji, jeżeli osoba udzielająca jej zastrzegła to ze względu na tajemnicę zawodową.

Kolejny przypadek to sprawa Renaty R., która wniosła o zasądzenie od swojego lekarza Szczepana B. m.in. kwoty 30000 zł za krzywdę spowodowaną naruszeniem jej dóbr osobistych przez ujawnienie w wywiadzie prasowym informacji objętych tajemnicą. Powódka udzieliła wywiadu dziennikarce, współpracującej z Federacją na Rzecz Kobiet i Planowania Rodziny. Opowiedziała w nim o przebiegu ciąży, problemach, z jakimi musiała się w tym czasie mierzyć, oraz o chorobie dziecka. Następnie dziennikarka skontaktowała się z pozwanym Szczepanem B. Lekarz, będąc w sporze z powódką, udzielił wywiadu, w którym szczegółowo podał informacje o przebiegu ciąży, ojcu dziecka oraz stosunku rodziców do niepełnosprawnej córki. Wiadomości te trafiły do artykułu, w którym użyto twierdzeń lekarza: „powódka chciała usunąć ciążę, bo mówiła, iż nie jej mąż jest ojcem dziecka, a także rodzice źle traktują córkę, są nieodpowiedzialni, z powodu ich zaniedbań dziewczynka z dużymi poparzeniami przywieziona została na pogotowie, dziecko jest wiązane sznurkiem”. Zarzuty wobec rodziców dziecka nie zostały jednak potwierdzone. Ponieważ doszło do ujawnienia informacji o pacjentce, objętych tajemnicą medyczną, lekarz odpowiadał karnie. Sąd Rejonowy warunkowo umorzył postępowanie na dwuletni okres próby, zobowiązując pozwanego do przeproszenia powódki oraz wpłacenia kwoty 1500 zł na rzecz Stowarzyszenia Pomocy Chorym z zespołem Turnera. Ponadto sąd cywilny I instancji uznał, że doszło do naruszenia dóbr osobistych powódki i nakazał wypłatę zadośćuczynienia w kwocie $10000 \mathrm{zt}^{48}$. W tym wypadku błędem lekarza było udzielenie w wywiadzie informacji objętych tajemnicą medyczną bez zgody. Gdyby Szczepan B chciał postąpić słusznie, to zamiast zarzucać rodzicom w wywiadzie stosowanie przemocy wobec własnego dziecka, powinien zawiadomić organy ścigania o możliwości popełnienia przestępstwa zgodnie z art. $240 \mathrm{k}$.k. Nic więc nie usprawiedliwia rozpowszechniania przez lekarza w mediach poufnych danych dotyczących pacjentki. Zbytnia otwartość lekarza w kontaktach z dziennikarzami może prowadzić do naruszenia prawa. W razie braku zgody na udostępnianie informacji pracownikowi medycznemu pozostaje poinformować media, że jest związany tajemnicą lekarską i na tej podstawie odmówić udzielenia jakichkolwiek wiadomości. Tym samym będzie zwolniony z obowiązku udzielania informacji prasie. Społeczny dostęp do danych o pacjencie jest ograniczony z uwagi na prymat prawa do prywatności. 


\section{Wnioski}

Konstytucja RP oraz polski system prawny gwarantuje obywatelom zarówno prawo do informacji, jak i prawo do prywatności. Jak zostało wskazane w artykule, konflikt pomiędzy nimi jest nieunikniony. Personel medyczny w trakcie wykonywania działalności zawodowej staje się posiadaczem licznych informacji, nie tylko natury medycznej, o swoich pacjentach. Dziennikarze zaś, korzystając z gwarantowanej im swobody pozyskiwania i rozpowszechniania zdobytych materiałów, mogą żądać do nich dostępu. Ustawodawca, chcąc zapewnić ochronę praw i wolności prywatnej sfery jednostki, pozbawił prasę absolutnego prawa dostępu do informacji i stworzył instytucję tajemnicy medycznej. Odpowiednie uregulowanie tego zagadnienia miało fundamentalne znaczenie dla zachowania pozytywnego wizerunku profesji lekarskiej oraz relacji lekarz - pacjent. Żelazną zasadą jest nieujawnianie informacji dotyczących pacjenta (pomimo istnienia obowiązku udzielania informacji mediom). Tylko w ustawowo określonych przypadkach podmiot udzielający świadczeń zdrowotnych uprawniony jest do informowania prasy, nie łamiąc zobowiązania do zachowania dyskrecji. Najlepszym sposobem legalizującym ujawnienie danych poufnych jest wyraźna, świadoma zgoda pacjenta, wyrażona w formie pisemnej. Inny sposób to przekazanie informacji w sposób zanonimizowany, czyli niepozwalający na identyfikację osoby będącej pod opieką lekarza. W pozostałych przypadkach pracownicy medyczni powinni odmówić dostępu do wiadomości objętych tajemnicą. Należy się wtedy liczyć z sytuacją, w której redaktor naczelny redakcji wystąpi z żądaniem doręczenia pisemnej odmowy, umożliwiającej egzekucję potrzebnych mu danych na drodze sądowej. Natomiast bezpodstawna odmowa udzielenia informacji będzie zawsze niezgodna z prawem. Podsumowując, z uwagi na to, że relacja między tajemnicą medyczną a działalnością dziennikarską dotyka ważnych, delikatnych, a tym samym wymagających subtelności, sfer życia człowieka, każdy przypadek powinien być analizowany w sposób indywidualny i wnikliwy. Brak absolutnego charakteru prawa dostępu do informacji publicznej w kwestiach objętych tajemnicą zawodową pozwala pracownikom medycznym zasłonić się przed obowiązkiem powierzania informacji prasie. Nie ma wątpliwości, że udzielona zgoda, zwalniająca z dyskrecji, tylko kreuje uprawnienie lekarza do informowania prasy, a nie nakłada na niego obowiązek.

\section{BIBLIOGRAFIA}

Ferenc-Szydełko E., Prawo prasowe. Komentarz, Warszawa 2013.

Gajda M., Tajemnica lekarska i dokumentacja medyczna po śmierci pacjenta - ważne zmiany w przepisach, http://gajda-adwokat.pl/tajemnica-lekarska-i-dokumentacja-medyczna-po-smierci-pacjenta-wazne-zmiany-w-przepisach.

Grzesiok-Horosz A., Ograniczenia dostępu prasy do informacji publicznej, https://sbc.org.pl/Content/305218/Grzesiok-Horosz_159-172.pdf?fbclid=IwAR0WMlSktMZEBOJ4csZNepS5CguGBYDDRlCO6LtiqqtpfDnn-AFdnqdBylc. 
Jabłońska J., Tajemnica lekarska jako podstawa zaufania w relacji pacjent - lekarz, MW 4/2012, https:// wil.org.pl/wp-content/uploads/4_2012.pdf.

Koenner M., Tajemnica lekarska - zgoda pacjenta i uprawnienia osoby bliskiej, https://podyplomie.pl/ aktualnosci/04678,tajemnica-lekarska-zgoda-pacjenta-i-uprawnienia-osoby-bliskiej.

Kosmus B., Kuczyński G., Prawo prasowe. Komentarz, Warszawa 2018, Legalis.

Kozłowski M., Sankcje za naruszenie tajemnicy medycznej, https://prawnieomedycynie.wordpress. com/2016/01/17/sankcje-za-naruszenie-tajemnicy-medycznej.

Kubiak R., Tajemnica medyczna, Warszawa 2015, Legalis.

Olejniczak M., Tajemnica lekarska i jej znaczenie nawet po śmierci chorego, https://www.mp.pl/etyka/ podstawy_etyki_lekarskiej/134112,kel-tajemnica-lekarska-i-jej-znaczenie-nawet-po-smierci -chorego.

Olejniczak M., Tajemnica lekarska - prawo rodzące zaufanie, (w:) M. Safjan (red.), Prawne i etyczne problemy współczesnej medycyny, Olsztyn 2016.

Pawlikowski J., O granicach tajemnicy zawodowej, czyli kiedy lekarz może ujawnić informacje o pacjencie, https://www.mp.pl/etyka/podstawy_etyki_lekarskiej/135919,o-granicach-tajemnicy-zawodowej-czyli-kiedy-lekarz-moze-ujawnic-informacje-o-pacjencie.

Sobczak J., Tajemnica lekarska, MW 8/2016, https://www.nil.org.pl/_data/assets/pdf_file/0010/112015/06-Sobczak.pdf.

Sobczak J., Tajemnica lekarska w obliczu zmian, MW 9/2017, https://www.nil.org.pl/_data/assets/pdf_ file/0011/128783/04-Sobczak.pdf.

Świtała K., Tajemnice zawodów medycznych - podstawowa charakterystyka, Legalis.

Taczkowska-Olszewska J., Obowiązek ochrony tajemnic medycznych a dziennikarskie prawo do informacji, MW 4/2012, https://wil.org.pl/wp-content/uploads/4_2012.pdf

Wierzchoń Z., Wykonuję zawód lekarz, lekarz dentysta. Komentarz do ustawy, Kodeks Etyki Lekarskiej, 2017. 